Bird Conservation International (2002) 12:211-230. (C) BirdLife International 2002

DOI: $10.1017 /$ S0959270902002137 Printed in the United Kingdom

\title{
Population census and habitat use of Rodrigues Warbler Acrocephalus rodericanus
}

\author{
DAVE A. SHOWLER, ISABELLE M. CÔTÉ and CARL G. JONES
}

\begin{abstract}
Summary
The Endangered Rodrigues Warbler Acrocephalus rodericanus is endemic to the Indian Ocean island of Rodrigues, one of the world's most devastated tropical islands, its native forest having been completely destroyed since human colonization three centuries ago. It is now found in thickets and woodland dominated entirely by non-native trees and shrubs. As a step to implementing conservation initiatives, a population census and habitat study was undertaken in April-June 1999. Using a combination of tape playback of song and point counts, at least 103 Rodrigues Warblers spread through nine wooded localities were observed, and a minimum population of 150 birds estimated. The majority $(78 \%)$ and highest densities $(2.3 / \mathrm{ha})$ were found in habitat dominated by one introduced invasive tree, the rose-apple Syzygium jambos. Warblers were also found in plantations dominated by mahogany Swietenia mahagoni, tecoma Tabebuia pallida and Norfolk Island pine Araucaria cunninghamii, but at much lower densities (0.5/ha). Warbler densities were highest in habitat with a dense structure of small branches. There was a strong positive relationship between one index of human disturbance (number of cut branches) and warbler densities. This low-intensity cutting may promote the growth of new shoots thus perpetuating the dense vegetation structure that Rodrigues Warbler favours. At two localities, one supporting an existing population of warblers and the other prone to extirpation (shown from previous surveys), vegetation structure and composition were similar between sites, hinting that in some currently unoccupied areas, habitat is probably suitable and other factors are operating to preclude colonization and establishment. Further ecological studies would be desirable, especially to investigate the effect of nest-predation by introduced mammals and other factors suppressing warbler population growth.
\end{abstract}

\section{Introduction}

The Indian Ocean island of Rodrigues is recognized as one of the world's most ecologically degraded tropical oceanic islands (Maunder et al. 1997). It was probably completely forested prior to human colonization in 1691 (Strahm 1989) and early accounts suggest a homogeneous forest interspersed with palms and Pandanus trees (Strahm 1993). By 1874 when the island was first scientifically described (Balfour 1879) it had already been extensively destroyed by fire, and the vegetation greatly altered from its state upon discovery. Today there is no remaining native forest and all but two of the 36-38 endemic flowering plant taxa are considered "Endangered" (Strahm 1993).

As early as 1761 Pingré noted that fires lit by settlers had begun to reduce the forest, and that there were introduced animals including cattle, goats, dogs, cats 
and rats, the latter two present in "legion" (Staub 1973). Oceanic island faunas are notoriously vulnerable to introduced predators. Cats are considered to be amongst the greatest decimators of native wildlife, especially passerines (Wace 1986), and rats (Rattus rattus and $R$. norvegicus) have colonised many oceanic islands where they have had a devastating effect on the native birds, reptiles and plants (Le Corre and Jouvetin 1997, Garcia 2000).

Rodrigues formerly supported at least 17 species of endemic vertebrates; a bat, at least 12 birds, two giant tortoises and two geckos (Cheke 1987). Today only three are extant: Rodrigues Fruit-bat Pteropus rodricensis and two birds, Rodrigues Fody Foudia flavicans and Rodrigues Warbler Acrocephalus rodericanus, the latter the subject of this study.

Rodrigues Warbler is a relatively poorly known species and listed as Endangered (BirdLife International 200o). Prior to 1974 when the first census was undertaken by Cheke (1987), information concerning its status and distribution was scant and somewhat anecdotal. In the past, it was "very common" (Slater 1875, in Cheke 1987) and probably spread throughout most of the island, with historical records from the north coast and from south-west Rodrigues on Plaine Corail (Newton 1865). After 1875, there is no further information about the species until 1930, when Vinson described it as "not rare" around St Gabriel (Cheke 1987) in the central uplands of the island. All records have subsequently come from the uplands, where in the absence of native forest, patches of scrub and woodland dominated by Syzygium jambos and other introduced trees act as refugia for the species.

From 1930 until the early 1970s, there are few recorded warbler observations, reflecting the paucity of ornithologists visiting the island and the difficulty of locating birds, as well as a declining population. Between 1955 and 1968, the Agricultural Department was engaged in extensive clearance of upland forests, which coupled with increased woodcutting for firewood, were thought to have had a detrimental effect on the warbler population (Cheke 1987). During this period, at least two birds were procured for museum specimens; Courtois collected one in 1957 (Staub 1973) and Gill, who made a "thorough search" in 1964, found only one bird which he shot (Cheke 1987). In March 1968, Cyclone Monica, the most severe cyclone recorded to have hit the Mascarenes, struck Rodrigues, and Staub (1973) considered it to have almost wiped out the warbler as he and two other observers failed to find any, despite intensive searches in December 1969. Thus a combination of factors (primarily deforestation, but also predation by introduced mammals, the 1968 cyclone and collection activities) probably contributed to reducing the warbler population to its lowest level by the end of the 1960 .

Based on limited habitat coverage Alès estimated a population of no more than 30 birds in 1971-1972 (Gomy 1973). In 1974 the first thorough census was undertaken, with nine pairs and 14 single birds observed (Cheke 1987). Sporadic censuses have been carried out since but these have been rather limited in coverage. However, the results of these indicated a gradual increase in numbers, all most certainly in response to an increase in forest cover (C. Jones pers. obs.), with one or two declines attributed to cyclones (Figure 1). The most recent survey undertaken prior to this study estimated the population to be $40-63$ birds in 1991 (C. Jones unpubl. data). To ascertain whether this population recovery was 


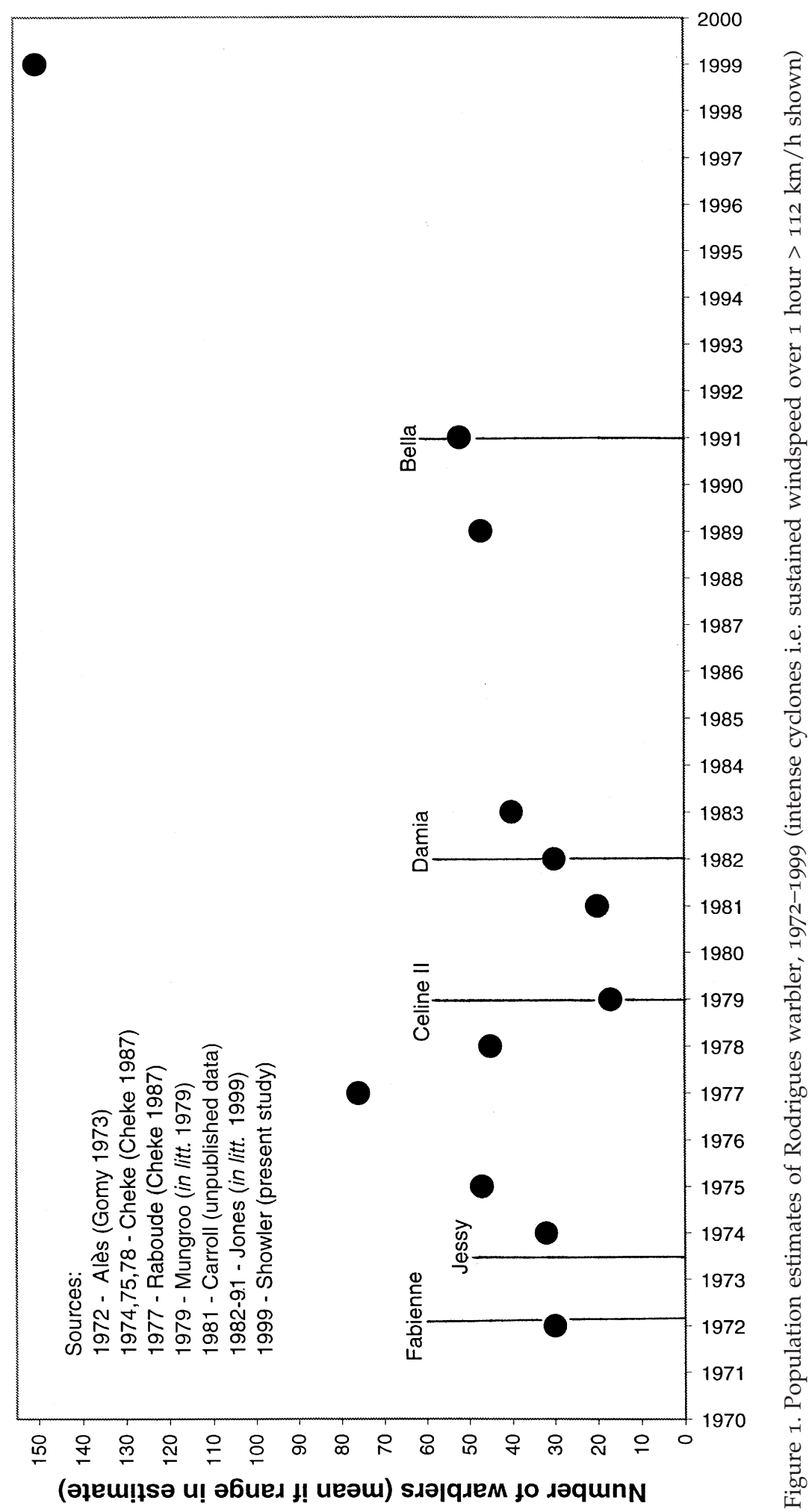


continuing and as a step towards implementing some conservation initiatives, a comprehensive population census of Rodrigues Warbler was undertaken in 1999 (Showler 1999). This allowed the identification of the species' present distribution and, combined with vegetation analysis, provided the first quantitative data on warbler-habitat associations.

\section{Materials and methods}

\section{Study species}

Rodrigues Warbler is a small insectivorous passerine about $135 \mathrm{~mm}$ in length, weighing 11 to $13 \mathrm{~g}$. It has a relatively long bill (hence its Creole name "zoiseau longbec $^{\prime \prime}$ ) and a long, graduated tail. The upperparts are olivaceous brown, with paler cheeks and pale yellow lores. The underparts are pale lemon yellow in fresh plumage, but when worn are greyish-white with only a slight wash of yellow. Rodrigues Warblers are unobtrusive, actively but quietly (apart from occasional song, calls and bill "clicks") gleaning invertebrate prey in the canopy and subcanopy. They are sedentary, with limited dispersal between woodlands, and pairs appear to be territorial throughout most of the year (Cheke 1987, Showler 1999).

\section{Study area}

Rodrigues (longitude $63^{\circ} 25^{\prime} \mathrm{E}$; latitude $19^{\circ} 43^{\prime} \mathrm{S}$ ) lies in the Indian Ocean almost $1,500 \mathrm{~km}$ east of Madagascar and $574 \mathrm{~km}$ east of Mauritius. It is one of three principal islands, along with Mauritius and Réunion, that comprise the Mascarene archipelago. Rodrigues is $18.3 \mathrm{~km}$ long by $8.5 \mathrm{~km}$ wide, covering an area of $110 \mathrm{~km}^{2}$. Its highest point reaches $396 \mathrm{~m}$ a.s.l. The terrain is mostly hilly with a 7-km-long central ridge, from which radiate numerous steep-sided valleys running down to the coast (Saddul 1995). About a quarter of the island is designated as "cattlewalk", i.e. barren grassland with scrub and occasional trees grazed by domestic cattle and goats, one third is under cultivation, and $7 \%$ is classified as "forest reserve" planted for watershed and soil protection (OSTROM and MSIRI 1986). Rodrigues has a population of about 35,000 people (Ministry of Rodrigues 1999), with villages and dwellings scattered throughout the island, and the main town Port Mathurin, situated on the north coast. The climate is subtropical with a hot, wet season from November to April, and drier, cooler cyclonic weather from May to October when south-easterly trade winds predominate. Cyclones occur almost annually between December and March (Strahm 1989).

\section{Rodrigues Warbler census method}

Preliminary field trials were undertaken to determine the best approach to conducting a population census. Line transects (Gibbons et al. 1996) were rejected as it was considered that impenetrability of the habitat and steepness of terrain in some areas would unduly influence their positioning, therefore rendering them non-random, and standardizing a rate of movement (except for a very slow one) 
would have been difficult. Fixed distance line transects, from which more reliable density estimates can be obtained compared with simple indices of the number of birds recorded per unit length of transect, were not feasible because of extremely limited visibility at many localities due to dense vegetation.

Point counts (Gibbons et al. 1996) per se were also rejected as these are applicable to more visible or vocal species; Rodrigues Warblers are unobtrusive and generally quiet. However, previous researchers (e.g. Cheke 1987, C. Jones pers. obs.) and trials during this study showed playback of taped song to be an excellent way to attract warblers. They respond quickly to playback (mean response time of 10 warblers during trials: $86 \mathrm{~s} \pm$ S.D. $96 \mathrm{~s}$ ) and from up to at least $60 \mathrm{~m}$ away, often approaching to within $3-4 \mathrm{~m}$. Therefore, a combination of point counts with playback was considered an appropriate census technique. For this purpose, the song of a Rodrigues Warbler was recorded and edited to produce a 3o-second tape. Two added advantages of playback over another effective method of attraction, i.e. "pishing" (blowing through ones lips and teeth to make a harsh hissing sound), were that the song could be played at a standard volume, and it often elicited song bursts from this otherwise inconspicuous species.

Playback points were established $70 \mathrm{~m}$ apart (trials suggested that this interpoint distance gave a good "overlap" of sound and ensured that areas were effectively saturated) throughout each locality. Areas that were impenetrable due to dense vegetation were covered as well as possible by walking around their periphery using playback at intervals of $50 \mathrm{~m}$ or less. The song recording was broadcast at a standard volume at each point at $30 \mathrm{~s}$ intervals, up to five times. If no warbler responded during this period a further $3.5 \mathrm{~min}$ was spent at each point looking and listening for birds. Therefore a maximum of 10 min was spent at each point. As soon as a bird responded, the tape was turned off to minimize disturbance.

All localities known to have supported Rodrigues Warblers in the last 25 years, (identified by Cheke 1987 and C. Jones pers. obs.) were surveyed in April-June 1999. Additionally, areas of woodland potentially suitable for colonization were searched by walking through the habitat (utilizing playback and pishing to aid detection) to assess presence or absence. Those areas found to support warblers were included in the surveys. As much of the habitat as possible was covered given the constraints of impenetrability due to dense vegetation and inaccessibility due to steepness of terrain.

For each bird seen or heard, the playback response time (taken as the time elapsed between the start of the first broadcast and detection by the observer) was recorded. The tail outline was sketched whenever possible, for individual recognition: throughout the study, adult Rodrigues Warblers were undergoing moult, and preliminary observations revealed that tail feather moult and regrowth characteristics were individual-specific and consistent enough at least over a period of three to four days, to allow subsequent identification of most birds. Weather permitting, each locality was resurveyed one or two days after the first survey. The predominant slope aspect at the point of observation was recorded, and later assigned to one of eight aspect categories: $0-45^{\circ}, 45^{-}-90^{\circ}, 90-$ $135^{\circ}, 135-180^{\circ}, 180-225^{\circ}, 225-270^{\circ}, 270-360^{\circ}$. The location of all birds, whether detected by playback or not, was recorded on a 1:5,000 scale field map. 


\section{Habitat survey}

Detailed habitat surveys were carried out over a four-week period from mid-May to mid-June 1999 at five localities: Mont Limon and Grande Montagne (hills), Gros Mangue (valley) and St Gabriel (low gradient), all found to support warblers. The fifth locality, Sygangue (hillside/valley), has held warblers periodically in the past.

Twenty $7 \times 7 \mathrm{~m}\left(49 \mathrm{~m}^{2}\right)$ quadrats were randomly positioned at each site (following the method of Kell 1996). To ensure approximately equal sampling effort on different aspects, each locality was stratified along the hill crest or valley bottom where appropriate. Within each quadrat the following habitat data were recorded:

(i) visual estimates of slope (assigned to one of four categories: 1 , flat $-5^{\circ} ; 2,5^{-}$ $15^{\circ} ; 3,15-30^{\circ} ; 4,>30^{\circ}$ ), canopy height, \% canopy cover, $\%$ ground flora cover (plants $<1.3 \mathrm{~m}$ tall) and \% rock cover;

(ii) the identity of all non-woody vascular plant species, the abundance of each classified using the DAFOR scale (Goldsmith 1991), where D is dominant, A is abundant, $\mathrm{F}$ is frequent, $\mathrm{O}$ is occasional, $\mathrm{R}$ is rare;

(iii) the identity of all woody plant species and the number of each taller than 1.3 m (breast height);

(iv) the diameter at breast height (dbh) of all shoots and branches of each woody species (including vines and lianas) to give a measure of branching structure and branching density. Each was assigned to one of 26 size classes: < $9 \mathrm{~mm}, 10-19$ $\mathrm{mm}, 20-29 \mathrm{~mm}$, etc. up to $249 \mathrm{~mm}$, and the remainder > $250 \mathrm{~mm}$;

(v) the number of cut branches as a measure of human disturbance.

\section{Data analysis}

Minimum population estimates for each locality were calculated by multiplying the number of warblers observed by the inverse of the proportion of available habitat surveyed. A $t$-test was performed on the playback response time data to identify if there was a significant difference in response time between singles and pairs of birds.

Rayleigh's test for circular uniformity (Zar 1996) was used to ascertain whether localities where warblers were observed were uniformly distributed by aspect. Simple linear regressions were performed on warbler densities against the habitat variables to identify significant relationships.

Principal components analysis (PCA) was performed in an attempt to identify which combinations of variables explained the largest proportion of variation in the dataset due to the large number of intercorrelated habitat variables. PCA was carried out on data from all five sites, and also on four sites, omitting Sygangue, the locality with no warblers (see Table 1 for data matrix).

A Kruskal-Wallis test was undertaken to test for differences in the mean count (per 20 quadrats) of branches between each of the size class categories and woody species density. Mann-Whitney $U$-tests for unmatched samples were performed on habitat variables, e.g. branching measurements and woody plant species densities, to compare vegetation structure and species composition between sites supporting warblers and those with none. These tests were undertaken to ascertain whether presence or absence of warblers could be related to habitat. 
Table 1. Data matrix of habitat variables recorded during 1999 vegetation surveys, with Rodrigues Warbler densities and PCA scores

\begin{tabular}{lccccc}
\hline Variables: & $\begin{array}{l}\text { Grand } \\
\text { Montagne }\end{array}$ & $\begin{array}{l}\text { Gros } \\
\text { Mangue }\end{array}$ & $\begin{array}{l}\text { Mont } \\
\text { Limon }\end{array}$ & $\begin{array}{l}\text { Saint } \\
\text { Gabriel }\end{array}$ & Sygangue \\
\hline Xcanopy height & 6.48 & 8.53 & 5.90 & 7.53 & 6.70 \\
X\% canopy & 69.25 & 58.25 & 72.25 & 58.25 & 67.0 \\
X\% ground & 29.7 & 41.2 & 11.60 & 42.60 & 22.60 \\
X\% rock & 2.9 & 2.70 & 1.00 & 0.70 & 11.80 \\
Xbranch density & 66.00 & 33.30 & 74.30 & 63.10 & 43.10 \\
Xwoody & 4.20 & 3.40 & 4.45 & 3.45 & 2.95 \\
Xnon-woody & 3.1 & 3.35 & 2.60 & 3.65 & 3.30 \\
Xcut branch & 2.75 & 2.70 & 4.35 & 3.55 & 3.65 \\
Warbler density & 0.7 & 0.5 & 2.3 & 1.5 & 0.00 \\
PCA Factor 1 & 0.36427 & -1.10731 & 1.49603 & -0.62103 & -0.13196 \\
PCA Factor 2 & 0.48869 & 0.28161 & 0.24230 & 0.74080 & -1.75339 \\
\hline
\end{tabular}

Variable abbreviations (mean refers to mean derived from 20 quadrats/site): Xcanopy height, mean percentage canopy height in metres; $\mathrm{X} \%$ canopy, mean percentage canopy cover; $\mathrm{X} \%$ ground, mean percentage vascular plant ground cover; $\mathrm{X} \%$ rock, mean percentage rock cover; $\mathrm{Xbranch}$ density, mean branching density; Xwoody, mean number of woody species; Xnon-woody, mean number of non-woody species; Xcutbranch, mean number of cut branches; Warbler density, warbler density/ hectare.

\section{Results}

\section{Survey coverage}

Survey coverage (using the point count/playback method) at most localities was high (65-100\%; Table 1), with two exceptions, Mt Cimetiere and Cascade Pigeon/ La Source. At Mt Cimetiere impenetrability of habitat due to dense stands of aloe Fucraea foetida, combined with steep, boulder-strewn slopes, made access very difficult. However, on the south-facing slope vegetation was patchy, stunted and unsuitable for warblers and only a rapid presence/absence assessment was undertaken. It was therefore estimated that at least $40 \%$ of the more densely vegetated areas that might support warblers was covered.

Cascade Pigeon/La Source is the largest contiguous area of woodland on Rodrigues. Here however, point counts were abandoned north of the dam (in the lower valley and adjacent slopes) when it became apparent that warblers were not present although presence/absence surveys were undertaken in the most likely looking areas. In the upper valley south of the dam, warbler distribution was patchy within only a 75 ha area. It was therefore estimated that $50 \%$ of suitable warbler habitat was covered.

\section{Rodrigues Warbler population estimate}

At least 103 individual warblers were observed, spread through nine wooded localities (see Figure 2; Table 2). Given the survey coverage, the minimum population was estimated to be 150 birds and the true population around 200. To avoid an inflated minimum estimate, juvenile birds being fed by adults $(n=4)$, those not positively identified as new birds on subsequent surveys $(n=5)$ and birds heard but not seen $(n=3)$ were excluded. At Grande Montagne, the repeat 


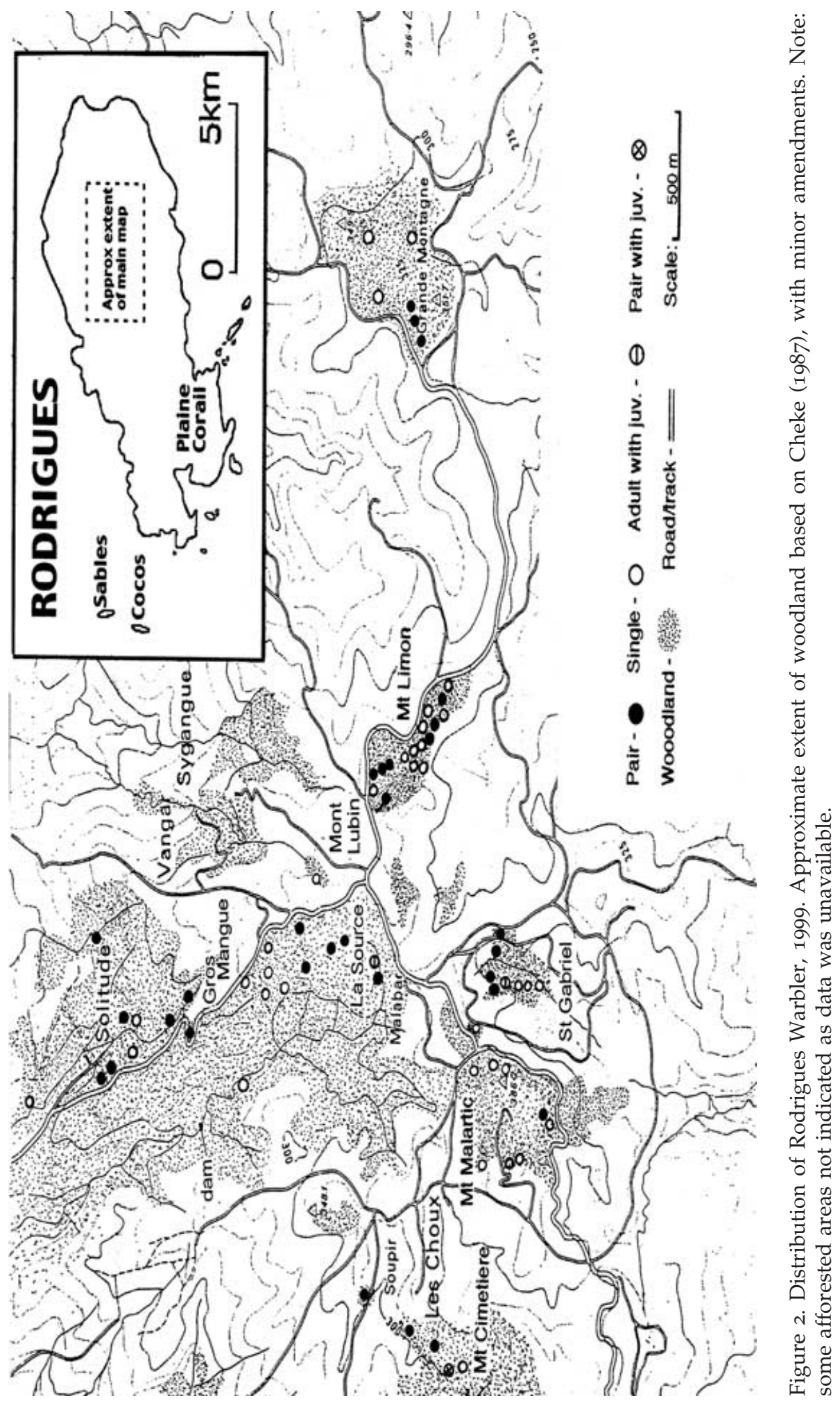


Table 2. Summary of Rodrigues Warbler observations, and density and population estimates for all localities surveyed, 1999

\begin{tabular}{|c|c|c|c|c|c|c|}
\hline Locality & $\begin{array}{l}\text { No. } \\
\text { Obs. }\end{array}$ & $\begin{array}{l}\text { Pairs }(p), \\
\text { singles (s), } \\
\text { juvenile (j) }\end{array}$ & $\begin{array}{l}\text { Estimated } \\
\text { area } \\
\text { of } \\
\text { woodland } \\
\text { (ha) }\end{array}$ & $\begin{array}{l}\text { Estimated } \\
\text { survey } \\
\text { coverage } \\
(\%)\end{array}$ & $\begin{array}{l}\text { Minimum } \\
\text { popn. } \\
\text { Estimate }\end{array}$ & $\begin{array}{l}\text { Density } \\
\text { estimate } \\
\text { (birds / } \\
\text { ha) }\end{array}$ \\
\hline $\begin{array}{l}\text { Cascade Pigeon/ } \\
\text { La Source }\end{array}$ & 19 & $\begin{array}{l}5 \mathrm{p}, 7 \mathrm{~s} \text {, adult } \\
\text { with } \mathrm{j}\end{array}$ & 74.2 & 50 & 36 & 1.0 \\
\hline Grande Montagne & 9 & $3 p, 3 s$ & $20.0^{\mathrm{a}}$ & 65 & 14 & 0.7 \\
\hline $\begin{array}{l}\text { Gros Mangue/ } \\
\text { Solitude/Vangar }\end{array}$ & 17 & $7 \mathrm{p}, 3 \mathrm{~s}$ & 40.9 & 80 & 21 & 0.5 \\
\hline Les Choux & 2 & 1pr & 1.0 & 100 & 2 & 2.0 \\
\hline Mont Cimetiere & 8 & $2 p, p$ with j & 12.0 & 40 & 18 & 1.5 \\
\hline Mont Limon & 24 & $8 p, 8 s$ & 13.2 & 80 & 30 & 2.3 \\
\hline Mont Malartic & 10 & $1 \mathrm{p}, 8 \mathrm{~s}$ & 15.3 & 70 & 14 & 0.9 \\
\hline Saint Gabriel & 13 & $\begin{array}{l}2 p, 5 s, \text { ad } \\
\text { with } j \times 2\end{array}$ & 9.0 & 80 & 14 & 1.5 \\
\hline Sygangue (petit) & 1 & is & 1.1 & 100 & 1 & 0.9 \\
\hline Sygangue & o & - & 8.3 & 100 & - & - \\
\hline Total & 103 & - & 195.0 & - & 150 & - \\
\hline
\end{tabular}

${ }^{a}$ Excludes plateau where non-native woodland has been cleared and replanted with native species, as yet not developed enough to provide warbler habitat.

survey was delayed twice due to heavy rainfall, thus there was a 3-day gap between the first and second survey, accounting for two of five birds that could not be definitely recognized as new during repeat surveys.

The highest number of warblers (24), and highest density estimates (2.3/ha), were recorded on Mont Limon. Lowest densities (0.5/ha) were observed in a fairly homogeneous area of mostly tall mixed plantation woodland incorporating Gros Mangue, Solitude and Vangar. One pair was located at Soupir, where warblers had not been recorded previously, in Syzygium-dominated woodland.

\section{Response time}

There was no significant difference in response time between singles or pairs of birds (mean \pm S.D., singles: 1 min $31 \mathrm{~s} \pm 67.48$, pairs: 1 min $11 \mathrm{~s} \pm 79.12, t=0.887$, $P=0.399$ d.f. $=41$ ). No test was undertaken on adults with young as the sample size was too small $(n=2)$. Although adults with young were seen on four occasions, two of these were located without use of playback.

If birds were in pairs, the male (discernibly brighter than the female when in fresh plumage) would typically approach first and give a few short song bursts, while the second bird (presumed to be a female but in some cases perhaps a full-grown immature) tended to hang back and sing less frequently.

\section{Distribution by aspect}

The areas harbouring warblers were not uniformly distributed by aspect (Rayleigh's Test for Circular Uniformity $z=9.473, P=0.001, n=95$ ). The majority (52\%) of observations had predominantly north-west-facing aspects, while $13 \%$ 


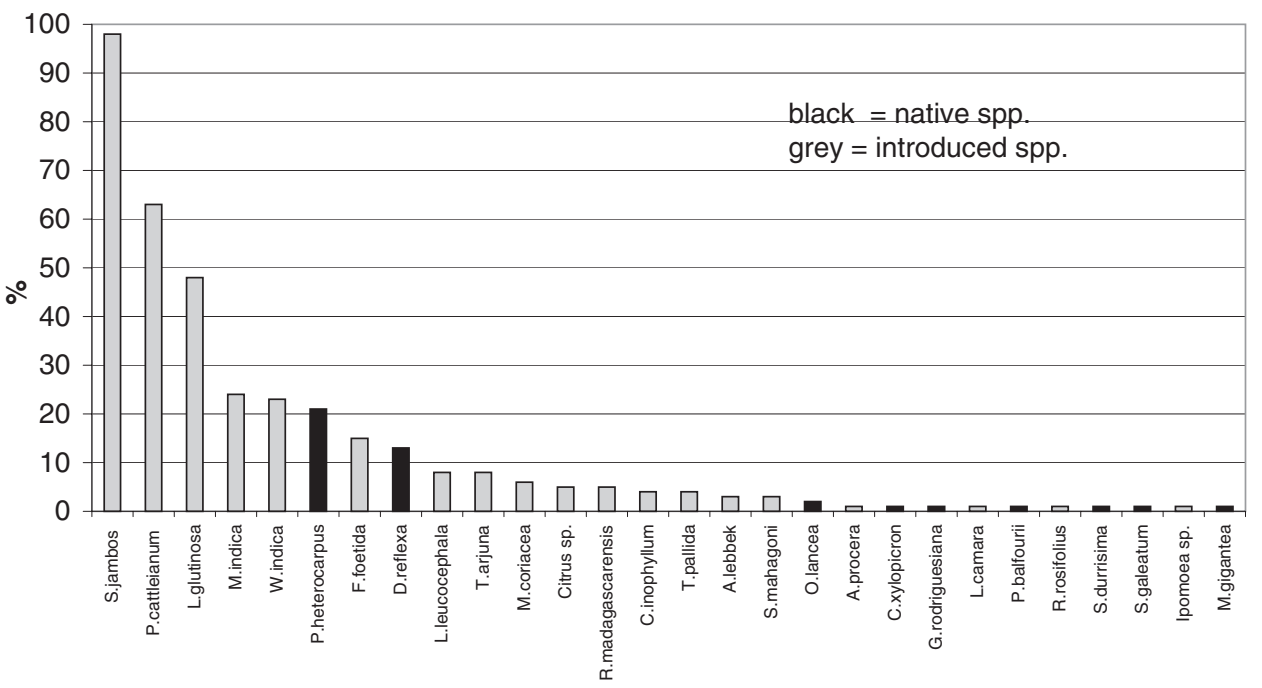

Figure 3. Incidence of occurrence of woody species and F. foetida in quadrats $(n=100)$, at Grande Montagne, Gros Mangue, Mt Limon, St Gabriel and Sygangue, 1999.

Key to plant names. Where possible, vernacular names are given in Creole (C:) and English (E:) after the scientific name. The IUCN threat category (Endangered, Vulnerable, Rare, Not Threatened) is given after each endemic species (indicated with an asterisk*). The status on Rodrigues is given for native (non-endemic) and introduced species (Strahm 1993).

Native species: *Carissa xylopicron C: Bois de ronde. Vulnerable; Dracaena reflexa var. angustifolia C: Bois de Chandelle. Not threatened; ${ }^{*}$ Gastonia rodriguesiana C: Bois blanc. Endangered; ${ }^{*}$ Mathurina penduliflora C: Bois Gandine. Rare; *Mucuna cf.gigantea C: Mort aux rats. Vulnerable. A rare liana; Olea lancea C: Bois malaya. Occasional shrub; *Pandanus heterocarpus C: Gros vacoa. Not threatened; *Pittosporum balfourii C: Bois bécasse. Endangered; Securinega durissima Endangered; ${ }^{*}$ Sideroxylon galeatum C: Bois de pomme, bois de fer. Endangered.

Introduced species: Albizia lebbeck Widely naturalized tree; Albizia procera A planted forestry tree, widely naturalized; Calophyllum inophyllum C: Takamaka. Naturalized tree; Citrus sp. A spiny, shrubby Citrus was occasionally recorded in quadrats. Not identified to species level; Furcraea foetida C: Aloes. E: Mauritian Hemp. Locally abundant, very invasive; Ipomoea spp. A vine/creeper, about 14 introduced spp. and two (lowland) natives on Rodrigues. Two non-native spp. (not identified) occasionally found in quadrats; Lantana camara C: Vieille fille. Very common, small invasive shrub; Leucaena leucocephala C: Acacie. Very common invasive tree; Litsea glutinosa C: Bois d'Oiseaux . Very common invasive tree; Mangifera indica C: Mangue, manguier E: Mango. Widely cultivated and naturalized tree; Mimusops coriacea C: Pomme Jacot. Cultivated, naturalised, locally invasive tree; Psidium cattleianum E: Chinese Guava. Locally very common shrub/tree, in uplands becoming invasive; Ravenala madagascarensis C: Ravenale. E: Traveller's Palm. Locally common tree, invasive along streambeds; Rubus rosifolius C: Framboise. Common scrambling shrub, becoming invasive in some areas; Swietenia mahagoni E: mahogany. Plantation tree, occasionally naturalized; Syzygium jambos C: Jamrosa. E: Rose-apple. Abundant, widespread, very invasive small tree/shrub; Tabebuia pallida C: Tecoma. Naturalized tree, in several localities becoming invasive; Terminalia arjuna Cultivated tree, becoming naturalized; Wikstroemia indica C: Herbe tourterelle. A small, spindly, invasive shrub. 
were on north-east, $7 \%$ on south-east and $28 \%$ on south-west aspects. Eight birds were not assigned an aspect as they were either on a plateau or hillcrest.

\section{Warbler-habitat associations}

A total of 27 woody plant species, including two vines/lianas, were recorded in the quadrats of the five focal localities. Syzygium jambos was the most frequently occurring woody species occurring in $98 \%$ of quadrats at a mean density of 15.6 plants/quadrat. Two other introduced trees, Chinese guava Psidium cattleianum (63\% of quadrats, 2.4 /quadrat) and Litsea glutinosa (48\% of quadrats, 3.6/ quadrat) were the next most prevalent species. Not until the sixth most frequently occurring species was the native flora represented by Pandanus heterocarpus, an endemic tree (21\% of quadrats, 1.9/quadrat) (see Figure 3). No other native species made a significant contribution to the overall densities of woody plant species recorded in the survey areas.

A Kruskal-Wallis test performed on the densities of branch diameters in the 26 size classes showed that there was a highly significant difference in the average number of trees/shrubs between sites $\left(\chi^{2}=27.5, P<0.001\right)$. However, although Sygangue (the locality not presently supporting warblers) was ranked fifth there was no significant difference in branching structure between here and Gros Mangue (a site supporting warblers) in Syzigium-dominated areas $(u=184.5$ $P=0.68$ Mann-Whitney $U$-test) (Figure $4 \mathrm{a}, \mathrm{b}$ ).

PCA proved inconclusive and did not provide meaningful explanations of the habitat dataset. Therefore, simple regression analysis was performed on warbler densities and the original habitat variables to identify relationships. The significant and near significant relationships from simple linear regressions are summarized as follows.

Warbler densities were significantly greater where intensity of cutting was higher (Adj $r^{2}=0.99, F=340.4$, d.f. $=1,2, P=0.003$ ) (see Figure 5). There were also significant positive relationships between warbler density and density of branches in the two smallest size classes (stem diameter $<0.9 \mathrm{~cm}$ and $1-1.9 \mathrm{~cm}$ ), i.e. as densities of small branches increased warbler densities increased (Adj $r^{2}=$ $0.855, F=17.7$, d.f. $=2,3, P=0.025$ and Adj $r^{2}=0.74, F=12.2$, d.f. $=2,3, P=0.040$ respectively). There was a weak relationship with the third smallest size class (Adj $r^{2}=0.63, F=7.5$, d.f. $=2,3, P=0.07$ ) but no relationships with the larger size classes. There was a negative relationship between warbler density and percentage vegetation ground cover (this was not correlated with canopy cover), i.e. as ground cover increased warbler densities decreased, but this only approached formal significance (Adj $r^{2}=0.84, F=16.5$, d.f. $=1,2 P=0.055$ ). There was a weak positive relationship between warbler density and $P$. cattleianum density at the four sites occupied by warblers, i.e. as $P$. cattleianum density increased warbler densities increased (Adj $r^{2}=0.82, F=14.5$, d.f. $=1,2, P=0.062$ ).

\section{Discussion}

Population estimate

There has been much practical and theoretical work on bird census techniques and determining real densities from census samples is a major problem (Roberts 
(a)

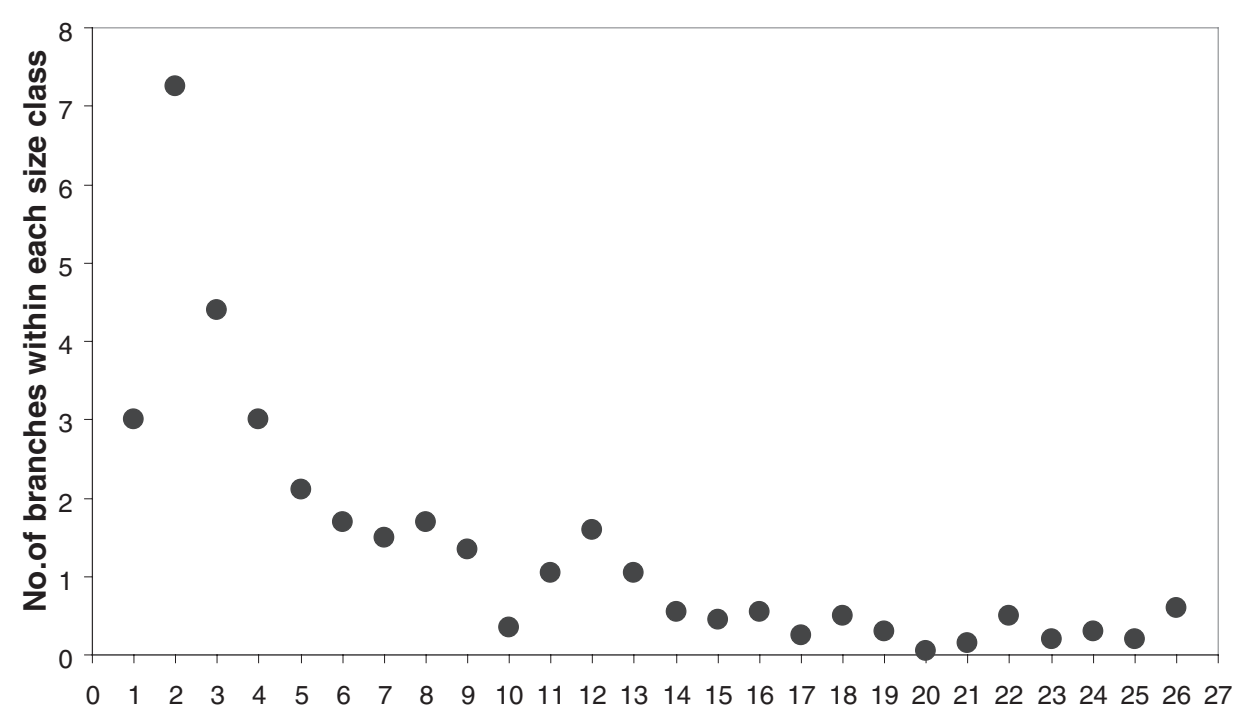

Branch diameter size class

(b)

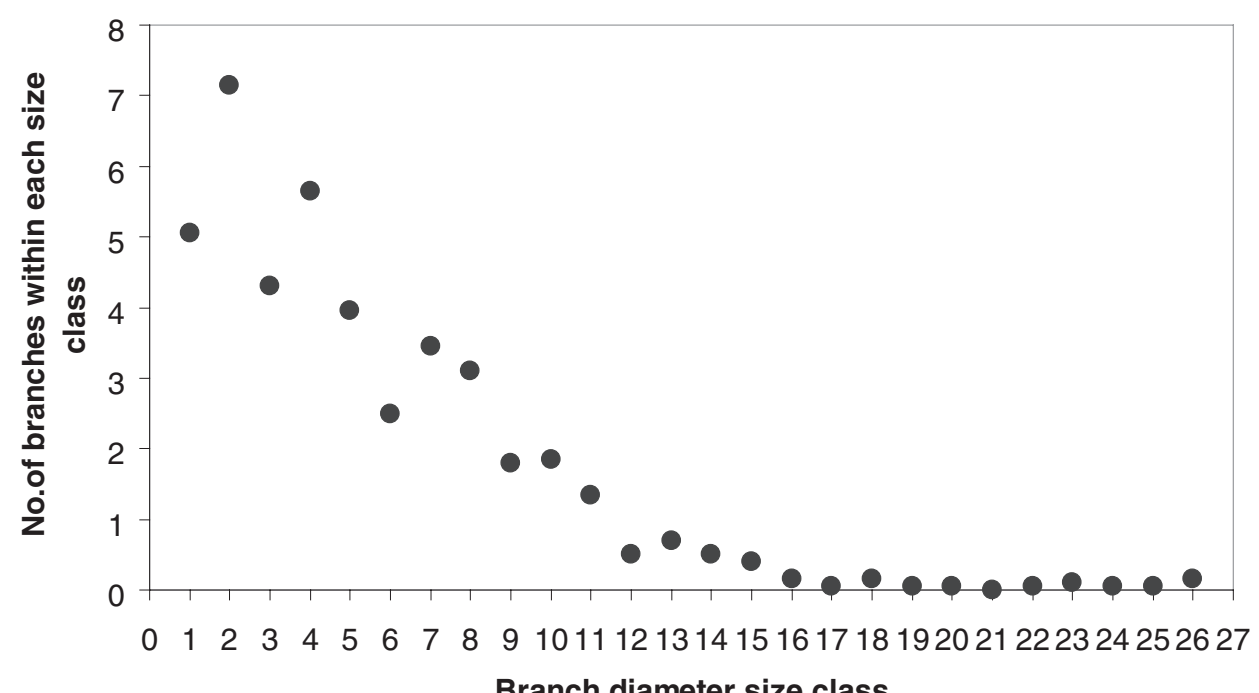

Branch diameter size class

Figure 4a. Mean number of branches/quadrat in each size class at Gros Mangue, a site with warblers. b. Mean number of branches/quadrat in each size class at Sygangue, a site with no warblers. 


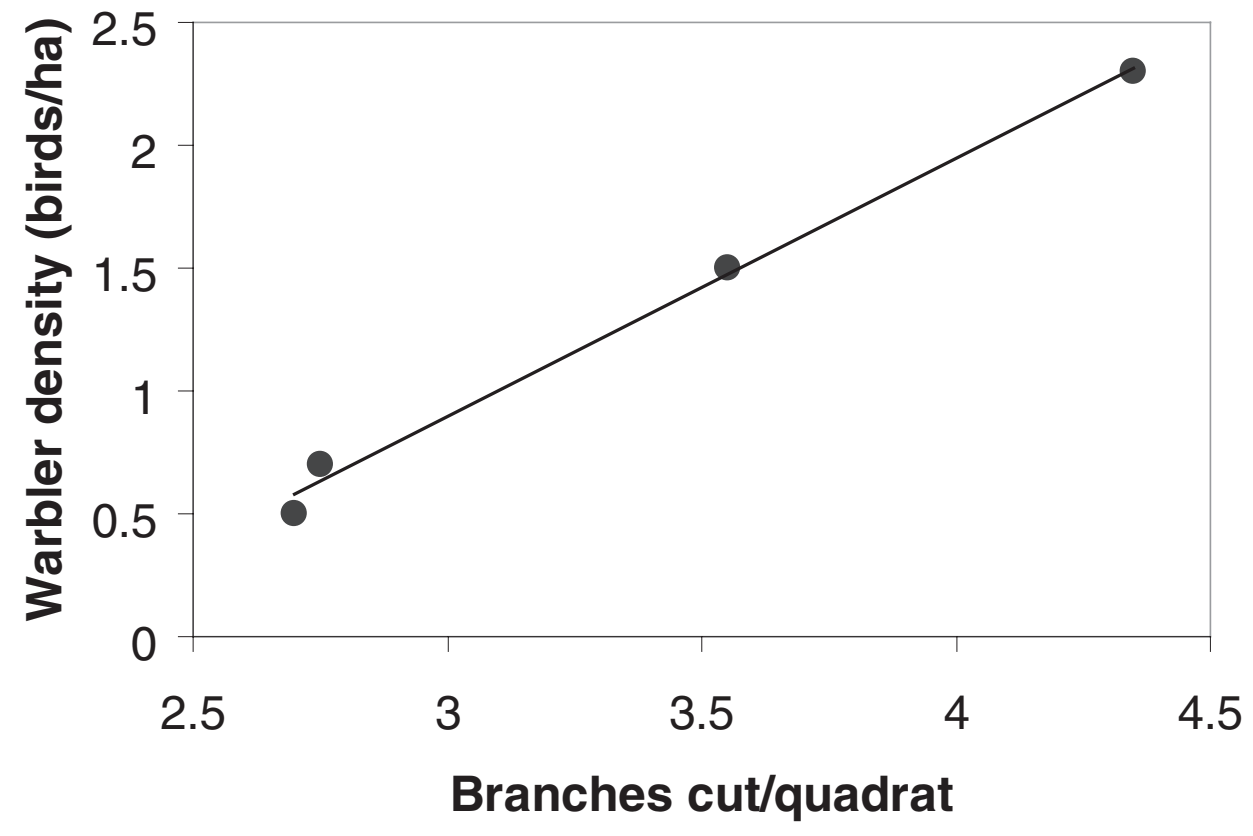

Figure 5. Regression of Rodrigues Warbler density on cutting intensity, 1999. Adjusted $r^{2}=0.991, F=340.4$, d.f. $=1,2, P=0.003$.

1991). This census was no exception. However, population estimates for most of the localities surveyed are considered reliable minimum population estimates due to high survey coverage. At Mont Cimetiere and Cascade Pigeon/La Source, where survey coverage was more limited and some assumptions were made about the area of habitat suitable for warblers, population estimates are more problematic, but nonetheless are still believed to give a reasonable indication of population size.

A cautious approach was taken to avoid an inflated population estimate. Juveniles were excluded from the population estimate calculations as juvenile mortality may be high (thus these may not have been recruited into the population). Similarly, warblers not positively identified as new birds on subsequent surveys were also excluded. Finally, no correction factor was incorporated for birds that may not have been detected. It is not possible to estimate what proportion of birds may have been missed and although detectability using playback appeared high and there was no significant difference in response times between singles and pairs of birds, it may be that a certain cohort, e.g. immatures, responded less well than adults. Given this, the minimum population is estimated to be 150 birds and the true population probably close to 200 birds, perhaps a little in excess of this. However, the effective population size (number of birds able to breed) is undoubtedly lower. Usually the effective population size is much smaller than the real population size for one or more reasons (Avise 1994). In the case of Rodrigues Warbler these reasons might include one gender being commoner than the other, and/or fluctuations in population size due to, for example, changes in habitat quality, cyclones, predators or disease. 
Table 3. Observed and estimated numbers of Rodrigues Warblers, 1974, 1975, 1991 and 1999

\begin{tabular}{lllll}
\hline Location & \multicolumn{4}{l}{ Number of warblers observed (estimated in parenthesis) } \\
\cline { 2 - 5 } & $1974^{\mathrm{a}}$ & $\begin{array}{l}1975^{\mathrm{c}} \\
\text { (territories) }\end{array}$ & $1991^{\mathrm{d}}$ & 1999 \\
\hline Cascade Pigeon/ La Source & 12 & $15^{-20}$ & $7-9(9-15)$ & $19(36)$ \\
Grande Montagne & 0 & 0 & $2(3-6)$ & $9(14)$ \\
G.Mangue/ Solitude & 3 & $3+$ & $7(7-10)$ & $17(21)^{\mathrm{e}}$ \\
Soupir & - & - & - & $2(2)$ \\
Mont Cimetiere & 0 & 0 & 0 & $8(18)$ \\
Mont Limon & 4 & $2+$ & $4(4-8)$ & $24(30)$ \\
Mont Malartic & 1 & Not checked & $6(6-10)$ & $10(14)$ \\
Petit Gabriel & 1 & Not checked & 0 & 0 \\
Roseaux & 0 & 1 & 0 & $0^{\mathrm{e}}$ \\
Saint Gabriel & 6 & $? 1$ & $2(2-4)$ & $13(14)$ \\
Mont Lubin & $\mathrm{O}$ & 0 & $2(2)$ & 1 \\
Sygangue & $\mathrm{O}^{\mathrm{b}}$ & 1 & 0 & 0 \\
Vangar & $\mathrm{O}$ & 1 & $(4)$ & $\mathrm{O}^{\mathrm{e}}$ \\
Other Areas & - & - & $33^{-35}(40-63)$ & $103(150)$ \\
Total & 32 & $(24-29+$ & & \\
\hline
\end{tabular}

${ }^{\mathrm{a}}$ Cheke (1987).

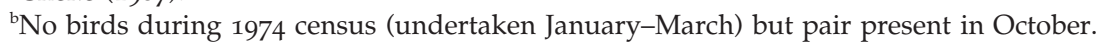

"Cheke (1987); figures refer to "active territories" which may represent pairs or single birds. dJones (in litt. 1999).

e A pair seen in the vicinity of Roseaux/Vangar (see Figure 2) is incorporated with Gros Mangue/ Solitude as there is no distinct boundary between these four sites.

\section{Distribution of subpopulations}

Observed and estimated numbers of Rodrigues Warblers at different localities in 1974, 1975, 1991 and 1999 indicated a slow increase in population size (Table 3). Since the 1974 census (Cheke 1987) there has been little change in distribution of Rodrigues Warbler apart from a recolonization of Grande Montagne, and a pair of birds at a new locality, Soupir. However, they seem to have become well established on Mont Cimetiere and St Gabriel where previously only small numbers had been recorded and where populations appeared prone to declines or even extirpation (C. Jones unpubl. data). The increase at St Gabriel is probably due to woodland regeneration coupled with reduced disturbance, this locality having been fenced for at least five years to exclude livestock, with only periodic cutting of grass for cattle fodder (J. Marla pers. comm.). Likewise at other localities, increases have probably occurred in response to regeneration.

Most warblers occur in woodland on north-west-facing slopes. This is not simply a reflection of woodland distribution for there are some large, wellwooded valleys, e.g. Anse Mourouk and Cascade St.Louis, facing south-east, where warblers do not occur and it is difficult to explain their absence. One possibility is that within these valleys, which are often severely hit by cyclones, trees become badly defoliated, thus making it difficult for birds to avoid exposure to wind and rain, and to forage (assuming food supply to be linked to amount of foliage) after the cyclone has passed (Cheke 1987). The physiography of these woods in comparison with areas where warblers are found, is also generally 
rather different in that they have a more open structure and higher proportion of native species (A. Cheke pers. comm.). However, there are densely vegetated areas within these valleys that would appear to constitute suitable Rodrigues Warbler habitat. Trees on north-west-facing slopes suffer less from defoliation due to lower windspeeds as they are to some extent protected from cyclones which come predominantly from a north-easterly direction (A. Malkovic pers. comm.), assuming that the trajectory of a cyclone (i.e. the path taken by the eye) is a guide to the direction of the strongest winds. North-west-facing slopes also tend to be damper as they are sheltered from the drying influence of southeasterly trade winds, and perhaps these moister conditions are preferred by Rodrigues Warbler.

\section{Population constraints}

Vegetation analysis showed habitat to be very similar at two localities, Gros Mangue supporting a population of warblers and Sygangue, where they are prone to extirpation. This suggests that in some currently unoccupied areas habitat is probably suitable and other factors are precluding colonization and establishment. Cyclones are known to affect adversely some warbler subpopulations, such as Sygangue (C. Jones in litt. 1999) where a survey conducted soon after an intense cyclone found no warblers where prior to the cyclone a small population had been present. However, only with more structured monitoring will the true effect of cyclones become apparent. Why warblers have not recolonized more areas and why the population recovery is so slow (given their potential reproductive capacity) may be because in addition to cyclones, other populationlimiting factors are operating. Indeed, a point that should be highlighted from the vegetation analysis is the almost total lack of correlation between warbler densities and habitat variables, further hinting that this is so. The impact of introduced predators including Black Rat Rattus rattus, Brown Rat R.norvegicus and feral cats Felis catus, has not been studied. However, nest-predation by rats is suspected to be one of the main factors suppressing recovery given that they are known to predate heavily on endemic birds in Mauritius (Safford and Jones 1998) and Black Rat in particular is well known for its devastating effect on arboreal birds, especially passerines (Moors 1983, Safford and Jones 1998).

\section{Habitat associations}

The dominance of non-native trees, especially Syzygium, in habitat used by Rodrigues Warbler is apparent. Within this Syzygium-dominated woodland, analysis suggests that a dense structure of small branches is important. There was also a strong positive correlation between number of recently cut branches and warbler densities, i.e. as cutting intensity (albeit low) increased, density increased. This low-intensity cutting may in fact perpetuate the preferred habitat by promoting growth of new shoots leading to a dense vegetation structure. It should be emphasized, however, that too much cutting would have a negative effect, for example as recorded at St Gabriel in the 1970s when the population decreased in response to excessive cutting of the woodland (A. Cheke pers. comm.).

There was a weak relationship between warbler densities and density of $P$. 
cattleianum. Of the 10 nests found in situ where the tree species in which the nest was recorded, five were in Psidium, four in Syzygium and one in Tabebuia (Cheke 1987). Given the much lower densities of Psidium compared with Syzygium in the woodlands, it may be that warblers selected for Psidium as the preferred nesttree, perhaps as it most closely resembles the branching structure of former native species.

Although only approaching formal significance, vegetation ground cover increased as warbler densities decreased. This is difficult to explain but one can speculate that perhaps predator densities are lower in areas with sparse ground cover where opportunities for foraging and concealment are reduced. The ground flora consisted mostly of short $(<50 \mathrm{~cm})$ herbaceous vegetation such as native Selaginella, ferns and grasses, with a frequently occurring small invasive shrub, Wikstroemia indica, rarely exceeding $1 \mathrm{~m}$ in height, and occasional tree seedlings. Unlike many Acrocephalus warblers that may forage close to the ground, Rodrigues Warblers usually keep to the woodland subcanopy and were almost always observed at least $2 \mathrm{~m}$ (up to about $12 \mathrm{~m}$ ) from the ground. Therefore, ground flora characteristics may not be an important component of Rodrigues Warbler habitat.

\section{Conservation of Rodrigues Warbler}

From observations dating back to 1938, when Wiehe noted Rodrigues Warblers in Eugenia (= Syzygium) thickets it has become apparent that Syzygium, a native to South-East Asia, is the dominant woody species in most areas where it is found. Marragon (1795 in Strahm 1989) provides the first mention of Syzygium on Rodrigues, and Bertuchi (1923, in Strahm 1989) wrote that most of the wooded parts of the island were covered in Jamrosa (= Syzygium). It reached its maximum coverage from 1910 to about 1955 but between 1955 and 1968 large areas of afforested land were cut and fragmented, adversely affecting the warbler population (Cheke 1974, 1987). Since this time there has been much woodland regeneration, many areas dominated by Syzygium, which is considered to have benefited the warbler. Ensuring that these wooded areas are retained is a conservation priority. Fortunately there are no real threats to the woodland as it is retained for watershed protection. Human disturbance from cutting for firewood has also been much reduced with a switch to gas as the main cooking fuel in recent years (R. Payendee pers. comm.), but an economic downturn could result in an upsurge in wood-cutting. However, Syzygium is considered one of the worst invasive plants on the island (Strahm 1989) forming dense stands of scrub and woodland up to $12 \mathrm{~m}$ tall effectively preventing regeneration of the slowergrowing indigenous species. Also listed as one of "the worst offenders" (in terms of invasiveness) is L. glutinosa, a tree native to Asia, which was found frequently in habitat occupied by the warbler during the vegetation surveys. A third introduced species, a shrub or small thicket-forming tree $P$. cattleianum native to Brazil, listed as "very invasive" (Strahm 1993), also frequently occurred but at lower densities. This species may in fact be the preferred warbler nest-tree. Kell (1996) states that exotic plant species are undoubtedly a major cause of habitat deprivation on the island but in the case of the three extant endemic vertebrates (the fruit-bat, fody and warbler), these stands of non-native trees and shrubs 
have been vital in providing a haven in the face of the native forest being destroyed. However, it is considered that all invasive tree species need to be removed if native forest is to regenerate (Strahm 1993). This raises some interesting conservation issues.

At one locality, Grande Montagne, designated a nature reserve and estimated to support a population of 14 warblers in 1999, management by the Rodrigues Forestry Services and the Mauritian Wildlife Foundation to restore native forest had being ongoing for 12 or so years. This has necessitated the gradual clearance of Syzygium and Litsea scrub/woodland (A. Maljkovic pers. comm.) resulting in loss of some warbler territories. However, the long-term benefit of native forest restoration will hopefully outweigh this short-term loss with recolonization as the native vegetation develops. Other sites where restoration of native forest may be undertaken will be selected in part on the basis of the prioritization of locations for in situ conservation (Parbery 1996). Future restoration projects should take into account the importance of each of these locations for the warbler but no major conflicts over flora vs. avian conservation are envisaged. This is because apart from Grande Montagne (ranked first), Mont Cimetiere (ranked fourth) and Mont Malartic (ranked sixth-seventh), other warbler localities have very few native plants and are thus far down on the restoration schedule. One also has to be realistic and acknowledge that because habitat restoration is very resource demanding, future projects will almost inevitably be on a relatively small scale and undertaken over a long time period.

Despite its slow recovery the long-term survival of Rodrigues Warbler is not assured. A species that becomes concentrated in one location it is at risk from localized catastrophes (Simberloff 1995); the distribution of Rodrigues Warbler remains very restricted and periodic intense cyclones must adversely effect at least some subpopulations. Also of concern is the possibility of introduction of another predator or avian competitor, which may tip the slow recovery into decline. Therefore, an attempt to increase its distribution and bolster the population would be desirable. The possibility of introducing warblers to the predatorfree islets of Ile Coco (approx. 25 ha) and Ile aux Sables (approx. 16 ha) off the west coast of Rodrigues, has been considered and feasibility studies were undertaken in 1993 (Bell et al. 1994) and subsequently (R. Safford pers. comm.). Marooning warblers on these ecologically rehabilitated islets would remove the predation problem, however they would be extremely vulnerable to cyclones as they are very exposed and there may be insufficient habitat to support them. Added to this, both islets are low-lying $(<5 \mathrm{~m}$ a.s.l) and when cyclones hit, coupled with a high tide (about every three years) they are inundated with seawater (A. Maljkovic pers. comm.). However, in view of the lack of other options, in the future if enough suitable habitat develops, it may be considered a strategy worth the risk. Translocations could use similar techniques to those successfully used for its congener, Seychelles Warbler A. sechellensis. As a conservation measure some Seychelles Warblers were translocated from their native island of Cousin to Aride in the early 1980 os and Cousine in 1990. These translocations have been a great success with populations now well established on both islands (Komdeur 1994). It is interesting to compare densities of Seychelles Warbler on these more-or-less predator-free islands where food is abundant and there is much suitable habitat, with Rodrigues Warbler on Rodrigues where introduced 
predators are present, food may be a limiting factor to reproductive success and habitat is restricted. Seychelles Warbler densities are two to seven times higher than that of Rodrigues Warbler on Mont Limon, which supports the highest density on Rodrigues. Looking from an island perspective, densities of Seychelles Warbler are 300-900 times greater on the Seychelle islands compared with Rodrigues Warbler on Rodrigues as a whole. Given that Rodrigues was mostly forested prior to man's arrival (Strahm 1993), and assuming the warbler had a fairly wide distribution as suggested by early observers (Newton 1865), even at low densities its population would probably have exceeded 10,00o birds.

The ecology of Rodrigues Warbler remains poorly known and further studies are required. In light of the findings of this study, investigations into factors suppressing population growth and inhibiting colonization of apparently suitable habitat would be especially useful. A priority would be to examine the extent of nest-predation by introduced mammals. Of those nests that escape predation, from scant field observations it would appear that despite laying three or so eggs per clutch, usually only one young is successfully fledged. Why is this? Food availability may be a limiting factor, especially in drought years and bearing in mind the suboptimal habitat possibly supporting only a sparse invertebrate fauna suitable to feed nestlings. Additionally, it would be desirable to implement a long-term standardized monitoring programme to record population trends, especially following management activities, and to identify changes in distribution. This would also serve to enable a better evaluation of the impacts of cyclones upon Rodrigues Warbler subpopulations, which at present are poorly understood.

\section{Acknowledgements}

Whilst undertaking the fieldwork D.A.S. would like to thank all the Mauritian Wildlife Foundation (MWF) staff for there help especially Aleks Maljkovic (Plant Conservation Officer), Richard Payendee (Assistant Conservation Officer) and Rina Nichols; and the Rodrigues Forestry Services, especially Jacques Leclerc Marla for his enthusiastic assistance when conducting vegetation surveys. The work was funded by MWF and the School of Biological Sciences, University of East Anglia, Norwich, U.K.

\section{References}

Avise, J. C. (1994) Molecular markers, natural history and evolution. New York: Chapman and Hall.

Balfour, I. B. (1879) The physical features of Rodriguez. Phil. Trans. R. Soc. Lond. 168: 289292.

Bell, B., Dulloo, E. and Bell, M. (1994) Mauritius offshore islands survey report and management plan. Wellington, New Zealand: Wildlife Management International.

BirdLife International (2000) Threatened birds of the world. Cambridge, U.K.: BirdLife International and Barcelona: Lynx Edicions.

Cheke, A. S. (1974) British Ornithologists' Union Mascarene Islands Expedition. Report on Rodrigues by A.S.Cheke, September 1974. Tring, U.K.: British Ornithologists' Union.

Cheke, A. S. (1980) Urgency and inertia in the conservation of the endangered island species illustrated by Rodrigues. Proc. IV Pan-Afr. Orn.Congr., 355-359. 
Cheke, A. S. (1987) Observations on the surviving endemic birds of Rodrigues. In A. W. Diamond, ed. Studies of Mascarene Island birds. Cambridge, U.K.: Cambridge University Press.

Collar, N. J., Crosby, M. J. and Stattersfield, A. J. (1994) The world list of threatened birds. Cambridge, U.K.: Birdlife International.

Diamond, A. W., ed. (1987) Studies of Mascarene Island birds. Cambridge, U.K.: Cambridge University Press.

Garcia, J. D. D. (2000) Selection and treatment of fleshy fruits by the Ship Rat (Rattus rattus L.) in the Canarian laurel forest. Mammalia 64 (1): 11-18.

Gibbons, D. W, Hill, D. and Sutherland, W. J. (1996) Birds. In W. J. Sutherland, ed. Ecological census techniques: a handbook. Cambridge, U.K.: Cambridge University Press.

Goldsmith, F. B., ed. (1991) Monitoring for conservation and ecology. London: Chapman and Hall.

Gomy, Y. (1973) Voyage en île d'amertume. Info-Nature Ile Réunion 9: 72-99.

IUCN (1996) IUCN Red list of threatened animals. Gland, Switerland: IUCN.

Jones, C. G. (1991) A report on the effects of Cyclone Bella on the endemic fody, warbler and fruit bat of Rodrigues. Unpublished report.

Kell, S. (1996) A vegetation survey of a potential genetic reserve on the Indian Ocean island of Rodrigues. MSc thesis, University of Birmingham, U.K.

Komdeur, J. (1994) Conserving the Seychelles warbler Acrocephalus sechellensis by translocation from Cousin Island to the Islands of Aride and Cousine. Biol. Conserv. 67: 143152.

Le Corre M. and Jouventin P. (1997) Ecological significance and conservation priorities of Europa Island (western Indian Ocean), with special reference to seabirds. Revue d'Ecologie-La Terre et La Vie 52 (3): 205-220.

Maunder, M., Culham, A. and Hankermer, C. (1997) Picking up the pieces: Botanical conservation of degraded oceanic islands. In P. L. Fiedler and P. M. Kareiva eds. Conservation biology Second edition. London: Chapman and Hall.

Mauritius Biodiversity Restoration Project. (1996) First Annual Report, July 1996.

Ministry of Rodrigues. (1999) Human population census. Government of Mauritius.

Moors, P. J. (1983) Predation by mustelids and rodents on the eggs and chicks of native and introduced birds in Kowhai Bush, New Zealand. Ibis 125: 137-154.

Newton, E. (1865) Notes of a visit to the island of Rodriguez. Ibis 51: 146-153.

OSTROM and MSIRI (1986) Les Sols de L'ile Rodrigues (technical circular new series, 3). Office de la Recherche Scientifique et Technique Outre-Mer and Mauritius Sugar Industry Research Institute, Mauritius.

Parbery, C. J. (1996) Priority habitat locations (Rodrigues). Unpublished report for Mauritian Wildlife Foundation, Mauritius.

Pingré, G. (1761) 1760-62, Relation de mon voyage de Paris à l'île Rodrigues. MS 1803, Bibliotheque Ste. Geneviève, Paris. In W. Strahm. Plant red data book for Rodrigues. Konigstein, Germany: Koeltz Scientific Books.

Roberts, (1991) Field monitoring: confessions of an addict. Pp 179-212 in F. B. Goldsmith, ed. Monitoring for conservation and ecology. London: Chapman and Hall.

Saddul, P. (1995) Mauritius: a geomorphical analysis. Moka, Mauritius: Mahatma Gandi Institute Press.

Safford, R. J and Jones, C. (1998) Strategies for Land-bird Conservation on Mauritius. Conserv. Biol. 12: 169-176.

Showler, D. A. (1999) Population census and habitat use of Rodrigues Warbler Acrocephalus rodericanus (Aves: Sylviidae). MSc thesis, University of East Anglia, Norwich, U.K.

Simberloff, D. (1995) Habitat fragmentation and population extinction of birds. Ibis 137: 105-111. 
Slater, H. H. (c. 1875) Notes on the Birds of Rodriguez. MS in bound quartro vol. entitled Indian Ocean 3, Madagascar - Mascarene islands (MSS), Newton Library, Cambridge University Zoology Dept. quoted by Cheke, A. in A. W. Diamond ed. (1987) Studies of Mascarene Island Birds. Cambridge, U.K.: Cambridge University Press.

Staub, F. (1973) Birds of Rodriguez. Proceedings of the Royal Society of Arts and Sciences of Mauritius, sessions 1968-1972, vol. IV, part I: 17-59.

Strahm, W. (1989) Plant red data book for Rodrigues. Konigstein, Germany: Koeltz Scientific Books.

Strahm, W. A. (1993) The conservation and restoration of the flora of Mauritius and Rodrigues. PhD thesis. University of Reading, Reading, U.K.

Wace, N. M. (1986) The rat problem on oceanic islands: research is needed. Oryx 20: 79-86. Zar, J. H. (1996) Biostatistical analysis. Third edition. Englewood Cliffs, NJ: Prentice-Hall.

DAVE A. SHOWLER and ISABELLE M. CÔTÉ ${ }^{1}$

School of Biological Sciences, University of East Anglia, Norwich NR4 7TJ, U.K.

CARL G. JONES

Mauritian Wildife Foundation, Ave Bois des Billes, Black River, Mauritius.

${ }^{1}$ Author for correspondence; e-mail: i.cote@uea.ac.uk

Received 30 October 2001; revision accepted 24 April 2002 